\title{
Career Growth, Career Commitment and Turnover Intention of Employees in Insurance Sector
}

\author{
Atar Thaung Htet \\ Yangon University of Economics \\ Corresponding author: atarthaunghtet48@gmail.com
}

\begin{abstract}
The main purpose of this study is to explore the career growth, career commitment, and turnover intention of employees in insurance sector. The specific objectives of this study are to examine the effect of career growth prospects on career commitment of employees in insurance sector and to investigate the effect of career commitment on turnover intention of employees in insurance sector. This study was conducted on the survey with 117 employees in insurance sector of Myanmar. The headquarters of general insurance companies in Myanmar were selected as the study area of this study. The survey was conducted with the supervisor, assistant managers and managers of insurance companies in Myanmar, not including the operational level employees as most of these junior staff's service year is not more than two years. It was found that professional ability development and salary growth have significant positive relationship with career commitment. In addition, the career identity of respondents have significant negative relationship with turnover intention of employees in targeted insurance companies. The study has concluded at the highest commitment level of employees regard on their career, the lower their intention to leave.
\end{abstract}

Keywords: Career Commitment, Career Growth Prospect, Turnover Intention

\section{Introduction}

Career commitment is determined by the development of personal goals, attachment to identifications, and involvement in those goals (Hall, 1976). The prospect of Myanmar insurance industry is booming nowadays. The increasing demand of labor market on the professional insurance workers has been leveraging the industry's growth rate. The abilities of employees in insurance sector are very critical for the development of this sector. The employees' mindsets on their career are key determinants for enhancing their capabilities to do their jobs.

The career growth plan of an organization is essential for achieving employees' career goals. If the employees move from one job to another, there is no sufficient experiences to do their job professionally. In Myanmar, employees in insurance sector need additional career development programs to enhance their career progress. Moreover, insurance companies design the effective human resource management program in order to enhance the employees' commitment level. The decision makers of insurance companies should emphasis on the career development trainings for their employees so that it would reduce employee's turnover intention for better career development. In other studies have profoundly highlighted the significant relationship between career commitment and career development program of employees. In addition, some of the findings suggests the negative relationship between career commitment and the turnover intention of employees (Bedeian, Kemery, \& Pizzolatto, 1991). 
In this turbulence business environment, the long term survival of organizations in the market depends on the number of factors such as strategic movement, resource configurations, and possess of expertise employees. The employees' emotionally attached to their career can improve their performance in workplace (Sahoo \& Das, 2011).The positive perceptions of employee about the organization's career growth program are mainly support their career commitment level and reduce their turnover intention regard this organizations.

\section{Rationale of the Study}

The government of Myanmar focuses on the designing the policies to liberalise regulations for creating the market economy. In previous years, government liberalized the policies regard with insurance sector and banking sector to facilitate the transformation process of market economy. Following the consequence of such liberalization, qualified foreign insurance providers receive the licenses to operate in local market. Myanmar government allows the full foreign investment in life insurance and joint ventures in general insurance.

The insurance companies have higher demand on the professional workers in order to develop their organization. The professional employees have the highest commitment level on their career. The sense of career commitment refers to the intellectually bound to the sense of action about their career. Numerous of former research findings have pointed out that the higher career commitment of employees could achieve their performance well.

Career commitment is based on employees' performance of receiving as well appreciating their enticement while matching their contribution which may also be rewarded corresponding with the venture. One of the influential factors is employee's physiological or emotional attachment that is responsible for the positive responses from organization through loyalty, warmth, belongings, and pleasure.

Organizational career commitment is largely planned and strategic procedures under the control of one wave and imply on entire management. Behavioral characteristics are mainly considered in the recital work done in an environment which requiring a continual improvement in current job and job mobility attentiveness.

This study is conducted for examining the effect of career growth prospect on career commitment and turnover intention of employees. There are many reasons to make this study. First of all, insurance market is recently booming in Myanmar, thus there is not enough professional insurance specialists to fulfill the labor demand. It indicates that insurance companies in term of how to develop the career growth program to train their existing employees which is the key determinant for nurturing professional employees in this industry. Second, the employees who are mostly young employees can easily switch from one career to another because of there is no sufficient career training for fresh graduates. The final one is, the employees' turnover rate has reached to a point in this industry because of the newly establishing insurance companies attempt to attracting professional employees in insurance field by offering them with better incentives which signifying the characteristic of oligopoly market.

This study supports the analysis of career growth prospect and career commitment of current employees in insurance sector for determining the effective career development program in respective organizations. The employees tend to work in one organization which is stable in the long run. Thus, the organizations need to make effective career growth program in order to improve career commitment and reduce the 
turnover intention within the organization. This study can suggest the proper solutions for studied insurance companies about their career development program.

\section{Objectives of the Study}

There are two research objectives of this study. The major objectives of this study are:

i. to examine the effect of career growth on career commitment of employee in insurance sector of Yangon Region; and

ii. to investigate the effect of career commitment on turnover intention of employees in insurance sector of Yangon Region.

\section{Literature Review}

This section presents the theoretical review of concepts relating to the study. Based on the theories and research works the conceptual framework is developed for conducting this research.

\section{Career growth and Career Commitment}

The concept of career growth was initially developed by Graen, Chun, Dharwadkar, Grewal, \& Wakabayashi (1997). Career growth could be classified into four dimensions (Weng \& Hu, 2009): career goal progress, professional ability development, promotion speed, and salary growth (an employee's perceptions of the speed, amount, and likelihood of increases in reward).

Career commitment can be defined as an employee's attitude towards his or her profession or vocation (Blau, 1985). Career commitment is specified by the development of personal career goals, the attachment to, identification with, and involvement in those goals (Colarelli \& Bishop, 1990). Previous research scholar identified the antecedents of career commitment. Irving et al. (1997) found that male employees had more career commitment than the female employees. Billingsley and Cross (1992) also found a positive correlation between the career commitment and age, which mean employees' career commitment tends to increase with age.

In an individual early career stage, career commitment is relatively low. However with increasing positive job involvement, clearer career goal, promotion and remuneration, improving job satisfaction and attaining a better person-job fit, the individual might build his or her career commitment (Goulet \& Singh, 2002; Darden, Hampton, \& Howell, 1989; Meyer, Allen, \& Smith, 1993). It is suggested that employees' career growth provided by their organizations should be able to meet employees' career goal, developing their professional abilities, and gain rewards from organizations, hence the employee career commitment will be increased.

\section{Career Commitment and Turnover Intention}

Price (2001) conceptualized turnover as an employee's movement over the boundaries of the organization. Cotton and Tuttle (1986) define turnover behavior as "the employee's perceived possibility of leaving the existing organization". Turnover intention corresponds to the conscious and deliberate to leave an organization for the purpose of finding alternative job opportunities in other organization (Meyer et al., 2002).

Conversely, Porter (1973) did point out earlier that career commitment had more integrity and persistence in terms of predicting the turnover intention, compared with 
job satisfaction. Employees with higher commitment to their organizations have higher expectation on their employers, and the degree to which those expectations are met might affect their attitude towards career and determine their decision to stay or leave (Chang, 1999). Indeed, in previous studies, career commitment was shown as a significant variable that could decrease turnover intention (Blau, 1985).

\section{Conceptual Framework of the Study}

This study is to examine the career growth prospect, career commitment, and turnover intention of employees in insurance sector at Yangon region. There are four indicators for career growth that include career growth progress, professional ability development, promotion speed, and salary growth. Career identify, career planning and career resilience are key factors for measure the career commitment of employees in insurance sector at Yangon Region. The conceptual frame work of this study is developed by using this measurement factors. The conceptual frame work of this study is shown in Figure (1).

In this model, career goal progress, professional ability development, and salary growth are the key determinants factors for career growth. In an individual early career stage, career commitment is relatively low. However, with the increasing positive job involvement, clearer career goal, promotion and remuneration, improving job satisfaction, and attaining a better person-job fit, the individual might build his or her career commitment (Goulet \& Singh, 2002).It is suggested that employees' career growth which is provided by their organizations should be able to meet employees' career goal, develop their professional abilities, and gain rewards from organizations, in turn, the employee career commitment will be increased.



Figure 1: Conceptual Framework of the Study

Source: Author, 2020

Employees with higher commitment to their organizations have higher expectation on their employers, and the degree to which those expectations are met might affect their attitude towards career, and determine their decision whether to stay or leave. If the employees are committed to their present career area, they would be more willing to pursue development opportunities in this area, which would better achieve their career expectations. But if they have low commitment to their career area, it would be possible for them to leave the current organizations that belong to this career area.

Therefore, this model is developed to examine the relationship between career growth and career commitment, and then it can be used to analyze the effect of career commitment on turnover intention. This model is relevant for current Myanmar insurance employees because the insurance companies try to improve the capacity of 
their employees' career in this market by designing effective career development program.

\section{Methodology}

This study focuses on the study of career growth, career commitment, and turnover intention of employees in insurance sector at Yangon region. Both primary and secondary data are used in this study. A structured questionnaire was used to collect the primary data and used the SPSS software to analyze the data. The multiple regression analysis method are used in order to analyze the data and to verify the research objectives. The secondary data are extracted from relevant websites, publication research paper and academic text books.

There are two types of insurance companies which are general insurance and life insurance companies. There are 11 private life insurance companies and 8 general insurance companies in Myanmar. The targeted respondents are the employees of general insurance companies because of the employees in this organization deals with various insurance services. The respondents of this study are middle management positions such as supervisor, assistant managers, and deputy managers due to their expertise in works which appears to be more valuable for their career. This study is used two stage sampling method for collecting primary data. In the first stage, three general insurance companies are selected for data collection. The targeted general insurance companies are Grand Guardian Tokio Marine General Insurance Co, Ltd (GGI Tokio Marine), KBZ MS General Insurance Co, Ltd, and AYA SOMPO Insurance Co, Ltd. In the second stage, 117 of employees are selected to answer the questionnaire while the method used data collection is simple random sampling. The selected sample size is calculated by using Yamane formula (1967).

In the data collection process, face-to-face interview and survey form is used to conduct this research. This study analyzes the career growth, career commitment and turnover intention of middle management positions at life insurance companies in Yangon Region. Due to the constraints of time as well as effort allocated to the research, this study only focused on the life insurance companies of Yangon Region and excluding the general insurance companies.

\section{Empirical Analysis}

This section provides the analyzed results for collected data regarding the career growth, career commitment, and turnover intention of employees in insurance sector at Yangon region. There are three steps involved to analyze the data. The reliability analysis is used in the first step in order to determine how consistent a certain scale and whether questions in the questionnaire are being effectively measured. The second step is to show the mean value of each variables by using descriptive statistics and the final one is to analyze the relationships of variables by using multiple regression analysis in order the support the research objectives. 


\section{Reliability Analysis}

The reliability of research instrument is attested using the Cronbach's alpha coefficient. Cronbach's alpha coefficient measures the degree of dependability, consistency, and stability of a scale. In this study, the reliability coefficients of eight variables are tested and the results are shown in Table (1).

Table 1 Reliability Analysis

\begin{tabular}{ccc}
\hline Variables & Cronbach Alpha & Number of Items \\
\hline Career Growth & & \\
Career Goal Progress & 0.613 & 4 \\
Professional Ability Development & 0.733 & 4 \\
Promotion Speed & 0.560 & 4 \\
Salary Growth & 0.517 & 4 \\
Career Commitment & & \\
Career Identity & 0.838 & 4 \\
Career Planning & 0.694 & 4 \\
Career Resilience & 0.494 & 4 \\
Turnover Intention & 0.910 & 10
\end{tabular}

Source: Survey Data, 2020

According to Sekaran and Bougie (2016), Cronbach's alpha coefficient values over 0.7 are acceptable and over 0.80 are good for the reliability of questionnaire. However, Nunnally and Bernstein (1967) agreed with Cronbach's alpha coefficient values from 0.50 to 0.60 are sufficient for the exploratory studies. Table (1) indicates that the alpha values of all variables are greater than 0.50 . Therefore, the variables in the questionnaire are reliable enough for analysis of the study.

Career Growth, Career Commitment, and Turnover Intention of Employees in Surveyed General Insurance Companies

In this study, there are three measurement attributes for career growth, three variables for career commitment. The mean value of each measurement are shown in respective tables. The analysis of mean value of each variables in research content can support the making of data analysis. The mean value of career growth is presented in Table 2 .

\section{Table 2 Career Growth of Employees in Surveyed Insurance Companies}

\begin{tabular}{|c|c|c|c|}
\hline Sr No. & Statements & Mean Value & Std.dev \\
\hline \multicolumn{4}{|c|}{ Career Goal progress } \\
\hline 1. & Moving close with career goals. & 3.2 & 1.124 \\
\hline 2. & Being relevant to career goals and vocational growth. & 3.6 & 0.842 \\
\hline 3. & Setting the foundations for realization of career goals. & 3.9 & 0.650 \\
\hline 4. & Providing the opportunities for career goals & 4.0 & 0.792 \\
\hline & Mean value of Career Goal Progress & 3.7 & 0.591 \\
\hline \multicolumn{4}{|c|}{ Professional Ability Development } \\
\hline 1. & Gaining new and job related skill. & 3.7 & 0.751 \\
\hline 2. & Improving the capacity. & 3.9 & 0.609 \\
\hline 3. & Accumulating the work experiences. & 4.1 & 0.763 \\
\hline 4 & Improving professional capabilities. & 4.2 & 0.681 \\
\hline \multicolumn{4}{|c|}{ Promotion Speed } \\
\hline 1. & Be fast the promotion speed in present organization & 2.8 & 0.779 \\
\hline 2. & Be high the probability of being promoted in present & 3.0 & 0.707 \\
\hline
\end{tabular}


3. Promotion speed is higher compare with previous organizations

4. Be promotion faster compared with my collages. Mean Value of promotion Speed

\section{$3.3 \quad 0.852$}

$3.0 \quad 0.436$

\section{Salary Growth}

1. Growing salary quickly in present organization.

$3.5 \quad 0.960$

2. High possibility of being increased salary.

3. Higher salary compare with other collages.

4. Being reasonable that current salary in exist organizations.

Source: Survey Data, 2020
$3.2 \quad 0.748$

$3.8 \quad 0.967$

$3.4 \quad 0.586$

According to the Table 2, the mean value of career goal progress, professional ability development, promotion speed, and salary growth are 3.7, 3.9, 3.0, and 3.5 respectively. The mean value of professional ability development is higher than other two factors. Most of the respondents are more likely to agree that their current job can well support their professional ability development. It can be assumed that the organizations could arrange the professional development program for their employee to improve their professional capacities that relates with career advancement.

There are three measurement factors for career commitment which are career identify, career resilience, and career planning. Table 3 describes the mean value of each variables of career commitment. This mean value is critical for analysis the collected data.

Table 3 Commitment of Employees in Surveyed Insurance Companies

\begin{tabular}{|c|c|c|c|}
\hline Sr No. & Statements & Mean Value & Std.dev \\
\hline \multicolumn{4}{|c|}{ Career Identify } \\
\hline 1. & Be an important part of respondents & 3.8 & 0.882 \\
\hline 2. & Having a great deal of personal meaning to respondents & 4.0 & 0.748 \\
\hline 3. & Strongly identifying with chosen line of career. & 3.9 & 2.771 \\
\hline 4. & Be the ideal vocation for life of career. & 3.6 & 0.865 \\
\hline \multicolumn{4}{|c|}{$\begin{array}{l}\text { value of Career Identify } \\
\text { Career Planning }\end{array}$} \\
\hline 1. & Having a strategy for achieve of career goals. & 3.9 & 0.836 \\
\hline 2. & $\begin{array}{l}\text { Identifying specific goals for achieve of career } \\
\text { development. }\end{array}$ & 3.9 & 0.732 \\
\hline 3. & $\begin{array}{l}\text { Thinking about personal development in this line of } \\
\text { career. }\end{array}$ & 4.2 & 0.828 \\
\hline 4 & $\begin{array}{l}\text { Spending the personal time for reading the job related } \\
\text { books and journals. }\end{array}$ & 3.6 & 0.865 \\
\hline \multicolumn{4}{|c|}{ Career Resilience } \\
\hline 1. & Emotionally attached to this line of career. & 3.9 & 0.732 \\
\hline 2. & Seeming too less that cost associated with this career. & 2.7 & 0.828 \\
\hline 3. & Feel not as the burden if the problem is rise in career. & 3.3 & 0.807 \\
\hline 4. & $\begin{array}{l}\text { Seeming too less that discomforts associated with line of } \\
\text { career. }\end{array}$ & 3.3 & 0.541 \\
\hline & Mean Value of Career Resilience & 3.3 & 0.314 \\
\hline
\end{tabular}

Source: Author, 2020

As mentioned in Table 3, the mean value of career identify, career planning, and career resilience are 3.8, 3.9, and 3.3. The mean value of career planning is higher than other factors. Most of the respondents are strongly agree about the career plan could support 
for the development of their career. The finding further denotes that respondents are more likely to consider about personal development throughout their career. The mean value of career resilience is lower than other two factors that point that employees are resistance to accept the burden of doing its career.

The final outcome of this study is turnover intention of employees in insurance sector. Higher turnover intention means the increasing cost of organizations in the longterm perspective. Thus, organizations need to retain their employees by designing effective career development program. The mean value of turnover intention is shown in Table 4.

\section{Table 4 Turnover Intention of Employees in Surveyed Insurance Companies}

\begin{tabular}{clcc}
\hline Sr N0. & \multicolumn{1}{c}{ Statements } & Mean Value & Std.Dev \\
\hline 1. & Intend to keep this vacation & 3.4 & 0.811 \\
2. & Be like search for new jobs in next year & 3.2 & 0.804 \\
3. & Making this job only better opportunity arise & 3.1 & 0.633 \\
4. & Remaining this job for the remainder of this career & 3.4 & 0.808 \\
5. & Satisfying with the training for advancement & 3.4 & 0.731 \\
6. & Satisfying with salary rate & 3.5 & 1.070 \\
7. & Planning to leave present employer as soon as possible & 2.8 & 0.580 \\
8. & Cannot leave the present employer in any circumstances & 3.1 & 0.797 \\
9. & Seriously consider leave for slightly better position & 3.4 & 0.849 \\
10. & elsewhere & & 0.732 \\
\hline \multicolumn{2}{c}{ Octively look for new job in this year. } & 2.9 & $\mathbf{0 . 1 8 5}$ \\
\hline
\end{tabular}

Source: Survey Data, 2020

As mentioned in Table 4, the overall mean value of turnover intention is 3.2 that is less than 3.5. It indicates the respondents are not likely to leave the current organizations. Most of the surveyed organizations can arrange the effective career development programs for retaining their employees. In addition, employees in insurance sector have greater commitment on their career.

\section{Effect of Career Growth on Career Commitment}

The multiple regression analysis method is used to test the effect of career growth on career commitment. In this study, there are four key factors to measure the career growth which are career goal progress, professional ability development, and promotion speed, and salary growth. The result of the analysis of relationship between career growth and career commitment is shown in Table 5.

As shown in Table 5, the specific models are used to explain the variables supposed to effect career commitment. As expected, professional ability development and salary growth are strongly significant relationship with career commitment. It means that one unit of fulfilling professional ability development can leads to increase the 0.308 level of career commitment. At the same time, one unit increases in salary growth can lead to the increment of 0.235 level in their career commitment.

As the employees are more expert in his or her career, they can be seem as more commitment on their career. The respondents of this study are trained by providing the technical skills, soft skills, and managerial skills trainings in their respective surveyed companies in order to develop their personal capacity in the long term. The employees with higher developed professional ability can be more committed in their career. The 
worker who performs their jobs professionally needs various working skills in order to emotionally attach with their careers.

In this study, the salary growth is the variable that significantly related with career commitment. People need not only intrinsic motivation factors but as well extrinsic motivation factors to perform their job more professionally. In the intrinsic motivated factors, salary growth is the key factor for driven the employee's motivations. The higher salary growth rate can bring the higher commitment level for their career. The employees need higher career commitment level to be more professional in their career life.

Table 5 Effect of Career Growth on Career Commitment

\begin{tabular}{|c|c|c|c|c|c|}
\hline \multirow[t]{2}{*}{ Model } & \multicolumn{2}{|c|}{$\begin{array}{l}\text { Unstandardized } \\
\text { Coefficients }\end{array}$} & \multirow[t]{2}{*}{$\mathrm{t}$} & \multirow[t]{2}{*}{ Sig } & \multirow[t]{2}{*}{ VIF } \\
\hline & B & Std. Error & & & \\
\hline (Constant) & 2.103 & .334 & 6.297 & .000 & \\
\hline \multicolumn{6}{|l|}{ Career Commitment } \\
\hline Career Goal Progress & -.042 & .060 & -.706 & .482 & 1.357 \\
\hline Professional Ability Development & $.308^{* * * *}$ & .068 & .425 & .000 & 1.417 \\
\hline Promotion Speed & -.135 & .086 & -1.577 & .118 & 1.551 \\
\hline Salary Growth & $.235^{* * * *}$ & .073 & .329 & .002 & 1.641 \\
\hline R Square & & & 2.96 & & \\
\hline Adjusted R Square & & & 2.70 & & \\
\hline F Value & & & $11.746 * * *$ & & \\
\hline Durbin Watson & & & 2.029 & & \\
\hline
\end{tabular}

Source: Survey Data, 2020

Notes: *** Significant at $1 \%$ level, $* *$ Significant al $5 \%$ level, $*$ Significant at $10 \%$ level

\section{Effect of Career Commitment on Turnover Intention}

Multiple regression analysis was used to test the effect of career commitment on turnover intention of employees in surveyed insurance companies. Career resilience, career identity and career planning used as the kay variables for measure the career commitment. The result of the SPSS output is shown in Table 6.

\section{Table 6 Effect of Career Commitment on Turnover Intention}

\begin{tabular}{|c|c|c|c|c|c|}
\hline \multirow[t]{2}{*}{ Model } & \multicolumn{2}{|c|}{ Unstandardized Coefficients } & \multirow[t]{2}{*}{$\mathrm{t}$} & \multirow[t]{2}{*}{ Sig } & \multirow[t]{2}{*}{ VIF } \\
\hline & $\mathrm{B}$ & Std. Error & & & \\
\hline (Constant) & 3.440 & .224 & 15.376 & .000 & \\
\hline Turnover Intention & & & & & \\
\hline Career Resilience & .037 & .055 & .662 & .509 & 1.082 \\
\hline Career Identity & $-.060 * *$ & .027 & -2.226 & .028 & 1.070 \\
\hline Career Planning & -.025 & .021 & -1.181 & .240 & 1.138 \\
\hline R Square & & & .079 & & \\
\hline Adjusted R Square & & & .054 & & \\
\hline F Value & & & $3.217 * * *$ & & \\
\hline Durbin Watson & & & 2.325 & & \\
\hline
\end{tabular}

Source: Survey Data,2020

Notes: *** Significant at $1 \%$ level, ** Significant al $5 \%$ level, * Significant at $10 \%$ level 
As shown in Table 6, the career identity has negative and significant relationship with turnover intention. One unit increase in career identity can lead to decrease of 0.60 level in employees' turnover intention. Career identity represents an individual's deep emotional relationship with their career. Employees who have more commitment on their career can reduce turnover rate. Career identity has implication for exploratory behavior, thus increasing the motivation and mindfulness that creates a circle which influencing the knowledge, skills, and serves as the base of proactivity and confidence in construction of one's future career. In addition, the increase the level of career identity can reduce the turnover rate of organizations. Lower employee turnover rate can bring the benefits for organizations.

\section{Findings}

This study concludes the effect of career growth on career commitment and the effect of career commitment on turnover intention of employees in insurance sector. This study highlights that the career planning has the highest mean value for their career commitment. In the career growth context, the mean value of professional ability development is the highest mean value among all of the factors. The mean value of turnover intention is 3.2 that highlights the moderate mean value which indicating that the respondents of this survey have not high intention to leave their organizations.

According to the regression analysis output, there are two findings for this study. The first one is the positive and significant relationship between professional ability development, salary growth, and career commitment. It points out that the employees are going to have the capacity to perform their works if the organizations arrange the relevant professional development program for them. At the same time, growth rate of salary can encourage their career commitment level. Every organizations need the highest commitment employees on their career in order to sustain long term growth of their organizations.

The last finding of this study is there is negative significant relationship between career identity (factors of career commitment) and turnover intention of employees in insurance sector. If the employees have the close emotional attached with their career, the result indicates that they couldn't make their decisions indubitably to leave their organizations. Organizations can maintain their turnover rate by providing the career development program for their employees in order to increase the commitment level in their respective career.

\section{Discussion}

These findings provide considerable implications for increasing career commitment level and maintaining employees in insurance sector. These suggestions make on the reasonable findings of this study. The findings of this study are mentioned in above section. The decision makers of insurance companies should make the effective personal development program for training their employees.

Based on this findings, insurance companies should hire the insurance experts from abroad to train their employees in the short term. In the long term, public universities should design insurance courses for giving the insurance degree in the education sector. The only academic degree program is not sufficient for nurturing the professionally competence employee. Thus, academic specialist and industry expertise 
should alliance to create the effective insurance program in order to encourage the skill development of insurance workers. The insurance companies should be make more internal training program to provide not only the technical knowledge but also the soft skills trainings for employees.

The higher salary growth rate is another critical factor for encourage the career commitment level of employees. The organizations should compensate the other benefit packages for their employees in order to increase their commitment level. The higher the employee's career identity concept can reduce the turnover rate. The favorable working environment can encourage the employee's emotionally attached to their career. In addition, employee's individual perceptions about their career need to be positive in order to success in their line of career. The management of insurance companies should arrange the favorable work environments and effective career development program for their employees in order to more commitment on their career.

\section{Acknowledgement}

My deepest thanks go to Professor Dr. $\mathrm{Nu} \mathrm{Nu}$ Lwin, Head of Department, and Department of Management Studies of the Yangon University of Economics, who gave the permission to complete this research. Finally, I really special thanks to respondents of this study. 


\section{References}

Bedeian, A. G., Kemery, E. R., \& Pizzolatto, A. B. (1991). Career commitment and expected utility of present job as predictors of turnover intentions and turnover behavior. Journal of Vocational Behavior, 39(3), 331-343.

Billingsley, B. S. \& Cross, L. H. (1992). Predictors of commitment, job satisfaction, and intent to stay in teaching: A comparison of general and special educators. The Journal of Special Education, 25(4), 453-471.

Blau, G. J. (1985). The measurement and prediction of career commitment. Journal of occupational Psychology, 58(4), 277-288.

Chang, E. (1999). Career commitment as a complex moderator of organizational commitment and turnover intention. Human Relations, 52(10), 1257-1278.

Colarelli, S. M. \& Bishop, R. C. (1990). Career commitment: Functions, correlates, and management. Group \& Organization Studies, 15(2), 158-176.

Cotton, J. \& Tuttle, J. M. (1986). Employee turnover: A meta-analysis and review with implications for research. The Academy of Management Review, 11(1), 55-70.

Darden, W. R., Hampton, R., \& Howell, R. D. (1989). Career versus organizational commitment: antecedents and con. Journal of Retailing, 65(1), 80.

Goulet, L. R. \& Singh, P. (2002). Career commitment: A reexamination and an extension. Journal of vocational behavior, 61(1), 73-91.

Hall, D. T. (1976). Careers in organizations. Goodyear Pub. Co. Making global partnerships work association of Japanese business studies, 75-89.

Irving, P. G., Coleman, D. F., \& Cooper, C. L. (1997). Further assessments of a threecomponents of occupational commitment: Generalizability and differences across occupations. Journal of Applied Psychology, 82(3), 444-452.

Meyer, J. P., Allen, N. J., \& Smith, C. A. (1993). Commitment to organizations and occupations: Extension and test of a three-component conceptualization. Journal of applied psychology, 78(4), 538.

Meyer, J. P., Stanley, D. J., \& Herscovitch, L. (2002). Affective, continuance, and normative commitment to the organisation: A meta-analysis of antecedents, correlates, and consequences. Journal of Vocational Behaviour, 61(1), 20-52.

Nunnally, J. C. \& Bernstein, I. H. (1967). McGraw-Hill series in psychology. Psychometric theory. New York, NY, US: McGraw-Hill.

Porter, L. W., \& Steers, R. M. (1973). Organizational work, and personal factors in employee turnover and absenteeism. Psychological Bulletin, 80(2), 151-176.

Price, J. L. (2001). Reflections on the determinants of voluntary turnover. International Journal of manpower.

Sahoo, C. K. \& Das, S. (2011). Employee empowerment: A strategy towards workplace commitment. European Journal of Business and Management, 3(11), 46 - 54.

Sekaran, U. \& Bougie, R. (2016). Research methods for business: A skill building approach. John Wiley \& Sons.

Weng, Q. X. \& Hu, B. (2009). The structure of career growth and its impact on employees' turnover intention. Industrial Engineering and Management, 14(1), 14-21.

Yamane, T. (1967). Sampling Formula. E-Book www albookez com. 